\title{
Nonlinear hedonic pricing: a confirmatory study of South African wines
}

\author{
This article was published in the following Dove Press journal: \\ International Journal of Wine Research \\ 19 March 2012 \\ Number of times this article has been viewed
}

\author{
David A Priilaid' \\ Paul van Rensburg ${ }^{2}$ \\ 'School of Management Studies, \\ ${ }^{2}$ Department of Finance and Tax, \\ University of Cape Town, \\ Republic of South Africa
}

Correspondence: DA Priilaid School of Management Studies, University of Cape Town, Private Bag, Rondebosch 7700, Republic of South Africa $\mathrm{Tel}+27216502994$

Fax +27 2I 6897570

Email david.priilaid@uct.ac.za

\begin{abstract}
With a sample of South African red and white wines, this paper investigates the relationship between price, value, and value for money. The analysis is derived from a suite of regression models using some 1358 wines drawn from the 2007 period, which, along with red and white blends, includes eight cultivars. Using the five-star rating, each wine was rated both sighted and blind by respected South African publications. These two ratings were deployed in a stripped-down customer-facing hedonic price analysis that confirms (1) the unequal pricing of consecutive increments in star-styled wine quality assessments and (2) that the relationship between value and price can be better estimated by treating successive wine quality increments as dichotomous "dummy" variables. Through the deployment of nonlinear hedonic pricing, fertile areas for bargain hunting can thus be found at the top end of the price continuum as much as at the bottom, thereby assisting retailers and consumers in better identifying wines that offer value for money.
\end{abstract}

Keywords: price, value, wine

\section{Introduction}

Within economics, "hedonics" is defined as the pleasure, utility, or efficacy derived through the consumption of a particular good or service; the hedonic model thereby proposes a market of assorted products with a range of associated price, quality, and characteristic differences and a diverse population of consumers, each with a varying propensity to pay for certain attribute assemblages. In the initial hedonic wine analysis, Oczkowski ${ }^{1}$ posited that the price of one bottle of wine relative to another would vary with the additional unit of the different characteristics inherent in one bottle relative to any other. Employing the conventional multiple regression framework, Oczkowski's study demonstrated how the relative price of a particular wine could thus be constituted as the summation of each of the constituent subprices that they attached to each of these attributes. Since then, numerous studies ${ }^{1-19}$ have seen hedonic modeling gain recognition as a form of wine price analysis.

With this analytical framework, our paper proceeds from the 2004 econometric valuation methodology of Priilaid and van Rensburg, ${ }^{18}$ which mapped out the relationship between wine price and value using sighted and blind "star-styled" quality ratings as explanatory variables. Assuming a straight-line relationship between quality rating and value, their linear model failed to provide sensible wine valuations at the extreme ends of the quality spectrum. By way of remedy, this study analyzes the selfsame price-quality continuum employing the so-called dummy-styled approach to address the likelihood of a nonlinear price-quality relationship. 
The approach of this paper is similar to the customer-facing orientation used in a subsequent study by Priilaid and van Rensburg, ${ }^{19}$ though here with a more recent and nonoverlapping dataset of red and white wines, two-and-a-half times the size of its predecessor. While the 2006 study ${ }^{19}$ was merely based on some 537 wines drawn only from red grape cultivars, this study employs a dataset of 1358 red and white wines tasted during the 2007 period; a significant difference. With this substantially updated and upgraded database, we thus seek to confirm that the dummy approach negates the possibility of value-for-money markers misleadingly being notified at the bottom end of the quality spectrum and neglected at the top. Across both red and white cultivars, confirmatory studies of this nature remain critical if econometric methods are to be sensibly applied in wine guides that assist consumers in the proper identification of wines purporting to offer value for money.

In this paper, we begin by reviewing the relevant literature, then introduce the data. Following this, we describe and contrast the linear and dummy valuation techniques. Analysis of the value-for-money construct is presented; in particular, where along the continuum of value it may be identified. Finally, conclusion is drawn.

\section{Theoretical framework and literature review}

Triplett ${ }^{20}$ notes that hedonic methods were developed and applied in price indices long before the conceptual foundations were wholly articulated. While according to Bartik ${ }^{21}$ and Goodman ${ }^{22}$ the term "hedonic" was first adopted in 1939 by Court, ${ }^{23}$ a number of earlier studies successfully presented a relationship between value and explanatory values of a hedonic nature. In this sense, therefore, while Court's study was the first "official" contribution to a theory of hedonic price functions, he certainly did not invent the approach, nor indeed did he ever claim to have done so.

The first to have successfully determined a hedonic function was, in all likelihood, a land economist of some sort. In his review of the formative literature, Oczkowski ${ }^{1}$ identifies Waugh's ${ }^{24} 1928$ study on “Quality factors influencing vegetable prices." Malpezzi ${ }^{25}$ and Freeman ${ }^{26}$ note that Haas $^{27}$ produced a hedonic study using sale prices as a basis for farmland appraisal in 1922. Metzemakers and Louw $^{28}$ trace it back even further, noting that Ricardo's ${ }^{29}$ theories were compatible with a characteristics approach to land value determination. His famous quote on the "original and indestructible power of the soil," on which his theory of agricultural land rents was based, refers to fertility differences between soils. Interpreted thus, Ricardo's approach clearly employed land characteristics to determine value, albeit his focus was on fertility only.

In the application of hedonic price theory to wine, the literature finds the varied application of four broad categories of explanatory candidate variables, namely: objective, sensory, climatic, and chemical wine characteristics. Objective characteristics cover nonambiguous aspects of a wine, including varietal, vintage, and country or area of origin. ${ }^{1}$ A wine's sensory characteristics include bouquet, body, and taste - components typically adjudicated by a panel of wine experts. Studies have demonstrated the marked extent to which expert assessment scores impact on the prices of wine. ${ }^{1,30}$ Climatic characteristics are used to determine the extent to which seasonal variations impact on the quality of wine from one season to the next. ${ }^{31,32}$ Lastly, chemical characteristics like sugar and alcohol content have also been applied to hedonic price functions. ${ }^{3}$

In 2004 and subsequently in 2006, van Rensburg and Priilaid $^{18,19}$ used the link between business and consumer costs to introduce a consumer-facing orientation to wine price hedonics. The rationale for this link is not new ${ }^{33}$ and notes that, together with profit, business costs sum to the seller's price (so often a construct in itself). Buyer costs accrue differently and include the time and effort spent in raising the requisite budget and thereafter locating the desired product. Assuming sufficient budget, a sale then becomes feasible if there is sufficient product value in the eyes of the buyer to warrant the purchase. The thrust of the consumer-facing model is that value should be perceived from the perspective of the buyer, not the seller. Accordingly, such models would eschew chemical and climatic factors, concentrating rather on objective and sensory wine characteristics (notably professional sighted and blind ratings) to develop consumerfriendly hedonic models. (See Priilaid and van Rensburg, ${ }^{19}$ Siegrist and Cousin, ${ }^{34}$ and Priilaid et $\mathrm{al}^{35}$ for an elaboration of the arguments on how and why consumers deploy wine expert ratings as risk-reducing proxies to guide buying and consumption behavior.)

It should also be noted that the persistent glut of wines and the ongoing decline of marginal wine farmers subsequent to the subprime housing crisis and bank failures post-September 2008 , both make the case for a consumer-facing orientation even more compelling. Were there an undersupply of wines and markets accordingly driven more by demand rather than supply, this argument might be less convincing. As South African wine critic Fridjhon noted recently, the Australian wine industry is severely vexed by problems of drought and oversupply. This was not the case during the global 
boom of 2005 when the wine industry was experiencing good times. By then Australia's 2025 strategic plan had been laid out and many of its strategic goals had already been achieved. However, the subsequent recession and drought have since led to severe complications. "Australia now has 100 million cases in oversupply - or one billion litres. Its surplus is bigger than SA's (entire) wine production, just to put it into perspective," says Fridjhon. ${ }^{36}$ A recent article in the New York Times ${ }^{37}$ noted similar effects in the USA where, in the last few years, sales of American syrah have gone into free-fall. "There's a joke going around West Coast wine circles. What's the difference between a case of syrah and a case of pneumonia? You can get rid of pneumonia. It would be funnier if it weren't so sad." 37

In Europe, too, the oversupply of commodity wines has forced a rethink of strategy, with European Union countries like Spain being granted quality driven planting permits at the expense of traditional table wine producing areas in countries like France. ${ }^{36}$ South Africa faces a similar set of problems, for despite being the seventh largest wine producer, only $5 \%$ of its farmers are turning a profit; again the result of poor bad weather conditions in 2009 and 2010, low prices, and rising costs. ${ }^{38}$ Assuredly for now, the consumer reigns supreme; and so to sell into such a market, wine retailers and producers need to be cognizant of such realities.

In South Africa large wine retailers like Pick 'n Pay, Makro, and Ultra Liquors have already taken cognizance, publishing quarterly wine catalogs with purchase recommendations based on rough estimates of the price-quality relationship of each wine cited. In a recent development specific to the topic of this paper, under the auspices of Ultra Liquors and the printing and distribution networks of Wine ${ }^{39}$ magazine, a value-for-money wine guide using hedonic price modeling, entitled WineIQ, was published. ${ }^{40}$ With such precedent in the public domain, it is becoming increasingly important that the "right" approach to such modeling be mapped out and verified. To this end, with an updated and expanded database, this confirmatory article reviews dummy-styled price modeling as a technique to remediate the problems associated with wine's nonlinear price-quality relationship.

\section{Description of the data}

Consumer-facing candidate variables for explaining wine prices appear in Table 1. These include wine varietal and blind and sighted quality ratings. Objective, climatic, or chemical characteristics were not explicitly included, the view being that these are implicitly captured in the ratings themselves. A discussion of each candidate variable follows.

\section{Wine varietal}

Along with red and white blended wines, eight South African-grown cultivars are assessed in this study: Cabernet Sauvignon, Merlot Pinotage, Pinot Noir, Shiraz, Chardonnay, Chenin Blanc, and Sauvignon Blanc. The cultivars selected constitute most of South Africa's national vineyard (see Table 2). Colombard is the third most prolifically planted grape and is excluded since most of its grapes are employed in the production of brandy. Based on its lofty prices and the profile of some of its producers, the ever-fickle though niche-like Pinot Noir is included in this study. However, marginal white wine equivalents, such as Sémillon and Viognier (respectively $1.05 \%$ and $0.62 \%$ of the national vineyard), are excluded due to lack of workable data. So too are Cinsaut (2.78\%), Ruby Cabernet (2.61\%), Hanepoort (2.60\%), and Cape Riesling (1.13\%) since the fruit from these cultivars is generally employed in the production of low-priced blends. ${ }^{41}$

The total sample of 1358 wines decomposes into two subsets: red wines: $(\mathrm{n}=896)$ and white wines $(\mathrm{n}=462)$. Each wine has assessments from both Wine (over the period January to December 2007) and the annual John Platter's South African Wine Guide ${ }^{42}$ (hereafter Platter's Wine Guide or Platter's). In aggregate, they represent the 2007 red and white wine market in South Africa. Table 3 depicts the dataset's spread of Wine and Platter's star ratings per varietal over this period.

The mean average price for the sample is R78.76. The price maximum, minimum, and standard deviation for the sample are R730, R8.50, and R58.32, respectively. Within the red wines, Pinot Noir is on average the most expensive wine per bottle (R108.24), followed by red blends (R96.59), Shiraz (R93.88), Cabernet Sauvignon (R83.34), Merlot (R73.52), and, finally, Pinotage (R70.64). Within the white sample, Sauvignon Blanc is on average

Table I Candidate variables explaining wine price

\section{Candidate variables}

I. Wine type (red: Cabernet Sauvignon, Merlot, Shiraz, Pinotage, Pinot Noir, red blends; white: Chardonnay, Chenin Blanc, Sauvignon Blanc, white blends)

2. Wine quality assessed sighted

a. Star ratings treated as numeric data

b. Star ratings treated as descriptive, dummy variables

3. Wine quality assessed blind

a. Star ratings treated as numeric data

b. Star ratings treated as descriptive, dummy variables 
Table 2 Varietals under analysis

\begin{tabular}{llll}
\hline $\begin{array}{l}\text { Varietals } \\
\text { analyzed }\end{array}$ & $\begin{array}{l}\text { \% of national } \\
\text { vineyard }\end{array}$ & $\begin{array}{l}\text { Total } \\
\text { hectarage }\end{array}$ & $\begin{array}{l}\text { National } \\
\text { ranking }\end{array}$ \\
\hline Chenin Blanc & 18.75 & 19053 & 1 \\
Cabernet Sauvignon & 13.36 & 13572 & 2 \\
Shiraz & 9.64 & 9794 & 4 \\
Chardonnay & 7.80 & 7927 & 5 \\
Sauvignon Blanc & 7.50 & 7661 & 6 \\
Merlot & 6.83 & 6941 & 7 \\
Pinotage & 6.39 & 6493 & 8 \\
Pinot Noir & 0.53 & 535 & 19 \\
\hline
\end{tabular}

Notes: White and red blends are also included in the study. Blends aside, alone, the eight varietals listed constitute more than $70 \%$ of South Africa's national vineyard. Data from Boom. ${ }^{41}$

the most expensive wine per bottle (R73.52), followed by Chardonnay (R71.59), white blends (R59.41), and, lastly, Chenin Blanc (R42.22).

\section{Measurements of wine quality}

Oczkowski ${ }^{2}$ observes that, unlike objective wine characteristics such as cultivar and vintage, a wine's quality is difficult to assess dispassionately and precisely. This, Oczkowski ${ }^{2}$ goes on to say, does not however negate the possibility of including professional wine ratings as candidate variables explaining price. As already observed, such ratings are important since, as risk-reducing heuristics, they effectively equip the wine consumer with the means to identify wines that offer the best available quality for price. ${ }^{19}$

In this study, the quality rating systems employed are Wine and Platter's Wine Guide. Metrics for intrinsic merit are derived from the former, which was launched in 1994, is published monthly, and assesses all wines via blind tastings. In the presence of a professional auditor, a four-judge panel presides, typically comprising a combination of wine professionals: sommeliers, wine-bar managers, wine makers, media people, and the like. Most will possess some form of professional accreditation. Scores are consensus based and tasting sessions always occur at the offices of Wine in Pinelands, Cape Town. Though "officially" based on a more fully calibrated 20-point scoring system, the five-star system is always cited for public consumption and is hence the scoring system employed in this study. Superlative wines receive five stars. Four-star wines are considered excellent. Good to very good wines score three stars. Wines deemed appealing receive a two-star rating. Average wines receive one star. A star rating of zero is awarded to unacceptable wines. Of the red wines assessed in this study, the mean average Wine score is 2.65 , with a maximum, minimum, and standard deviation for the sample of 4.5, 1.5, and 0.90, respectively. Equivalent figures for the

Table 3 Number of wines assessed per varietal - as graded by John Platter's South African Wine Guide ${ }^{42}$ and Wine ${ }^{39}$ star ratings, respectively

\begin{tabular}{|c|c|c|c|c|c|c|c|c|c|c|c|c|}
\hline Cultivar & 0 & 0.5 & $\mathbf{I}$ & 1.5 & 2 & 2.5 & 3 & 3.5 & 4 & 4.5 & 5 & Sum \\
\hline \multicolumn{13}{|c|}{ Platter's ratings for 2007 wines } \\
\hline Cabernet Sauvignon & & & & I & 3 & 7 & 8 & 40 & 41 & 16 & & 116 \\
\hline Merlot & & & & & 6 & 4 & 23 & 38 & 27 & 8 & & 106 \\
\hline Pinotage & & & & 3 & & 9 & 20 & 28 & 25 & 10 & & 95 \\
\hline Pinot Noir & & & & & I & I & 6 & 8 & 4 & 5 & & 25 \\
\hline Shiraz & & & & I & 2 & 8 & 37 & 65 & 65 & 34 & & 212 \\
\hline Red blends & & & & & II & 21 & 43 & 100 & 111 & 56 & & 342 \\
\hline Chardonnay & & & & 2 & I & 5 & 22 & 33 & 55 & 18 & & 136 \\
\hline Chenin Blanc & & I & I & 5 & 4 & 12 & 30 & 23 & 18 & 6 & & 100 \\
\hline Sauvignon Blanc & & & I & 3 & 4 & 7 & 15 & 45 & 56 & 20 & & 151 \\
\hline White blends & & & & 2 & 6 & 6 & 19 & 17 & 15 & 10 & & 75 \\
\hline & & I & 2 & 17 & 38 & 80 & 223 & 397 & 417 & 183 & & 1358 \\
\hline \multicolumn{13}{|c|}{ Wine ratings for 2007 wines } \\
\hline Cabernet Sauvignon & I & & 7 & & 9 & 27 & 38 & 21 & 13 & & & 116 \\
\hline Merlot & 6 & & 19 & & 24 & 23 & 19 & 10 & 5 & & & 106 \\
\hline Pinotage & 2 & & 11 & & 17 & 27 & 20 & 10 & 7 & I & & 95 \\
\hline Pinot Noir & 1 & & 3 & & 4 & 4 & 6 & 3 & 4 & & & 25 \\
\hline Shiraz & I & & 15 & & 41 & 47 & 66 & 21 & 17 & 4 & & 212 \\
\hline Red blends & II & & 21 & & 57 & 68 & 92 & 50 & 41 & I & I & 342 \\
\hline Chardonnay & 1 & & 4 & & 27 & 34 & 45 & 15 & 10 & & & 136 \\
\hline Chenin Blanc & 2 & & 9 & & 24 & 23 & 21 & 6 & 10 & 3 & 2 & 100 \\
\hline Sauvignon Blanc & I & & 10 & & 33 & 43 & 36 & 15 & 12 & I & & $|5|$ \\
\hline \multirow[t]{2}{*}{ White blends } & 0 & & 4 & & 17 & 13 & 10 & 17 & II & 3 & & 75 \\
\hline & 26 & & 103 & & 253 & 309 & 353 & 168 & 130 & 13 & 3 & 1358 \\
\hline
\end{tabular}


white wine sample are mean, 2.70; maximum, 5; minimum, 0 ; and standard deviation, 0.82 .

The Platter's Wine Guide team taste their wines sighted and employ the selfsame five-star or 20-point scoring system. Over the 896 red wines tasted, the mean average Platter's score is 3.61 , with a maximum, minimum, and standard deviation for the sample of $4.5,1.5$, and 0.90 , respectively. In comparison to the reds, the mean average Platter's score for the 462 white wines tasted is 3.50 , with a maximum, minimum, and standard deviation for the sample of $4.5,1.5$, and 0.73 , respectively.

\section{Results and discussion Methodology and model construction}

Using the ordinary least squares (OLS) regression analysis methodology, the cross-section of wine prices (price) is modeled for the similar goods $\mathrm{i}=1 \ldots \mathrm{n}$ as a function of $\mathrm{K}$ consumer desirable $\left(\mathrm{CD}_{\mathrm{k}}\right.$ where $\left.\mathrm{k}=1, \ldots, \mathrm{K}\right)$ characteristics. Thus:

$$
\text { Price }_{\mathrm{i}}=\alpha+\sum_{\mathrm{k}=1}^{\mathrm{K}} \mathrm{b}_{\mathrm{k}} \mathrm{CD}_{k}+\varepsilon_{\mathrm{i}}
$$

where $\alpha=$ the intercept term as estimated by OLS, $b=$ the $\mathrm{K}$ slope coefficients as estimated by OLS, CD $=$ the $\mathrm{K}$ "consumer desirables," and $\varepsilon=$ a random residual error term following classic assumptions.

The classification of the explanatory variables (CD) includes only those that are likely to constitute perceived value for the consumer, in this case blind and sighted tasting scores as conducted by Wine and Platter's Wine Guide, respectively. The model thus disaggregates the price of each wine into value and mispricing components. In so doing, the derived fitted values equate to estimates of intrinsic value, the difference between value and price reflecting the level of mispricing $\left(\varepsilon_{\mathrm{i}}\right)$ in each instance. As per van Rensburg and Priilaid, ${ }^{18}$ a wine's price and valuation may thus be charted, yielding a "value frontier" region where maximum value, relative to price, may be observed. Accordingly, ordinal and dummy valuation models are estimated and compared as per the equations:

$$
\begin{aligned}
\mathrm{OV}_{\mathrm{i}}= & \alpha+\mathrm{b}_{1} \text { cab }_{\mathrm{i}}+\mathrm{b}_{2} \text { merlot }_{\mathrm{i}}+\mathrm{b}_{3} \text { pinot noir }_{\mathrm{i}} \\
& +\mathrm{b}_{4} \text { shiraz }_{\mathrm{i}}++\mathrm{b}_{5} \text { red blend }_{\mathrm{i}}+\mathrm{b}_{6} \text { chardonnay }_{\mathrm{i}} \\
& +\mathrm{b}_{7} \text { sauv blanc }_{\mathrm{i}}+\mathrm{b}_{8} \text { white blend } \\
& +\mathrm{b}_{9} \text { Wine Stars }_{\mathrm{i}}+\mathrm{b}_{10} \text { Platter Stars }_{\mathrm{i}}
\end{aligned}
$$

$$
\begin{aligned}
\mathrm{DV}_{\mathrm{i}}= & \alpha+\mathrm{b}_{1} \text { cabernet }_{\mathrm{i}}+\mathrm{b}_{2} \text { merlot }_{\mathrm{i}}+\mathrm{b}_{3} \text { pinot noir }_{\mathrm{i}} \\
& +\mathrm{b}_{4} \text { shiraz }_{\mathrm{i}}++\mathrm{b}_{5} \text { red blend }{ }_{\mathrm{i}}+\mathrm{b}_{6} \text { chardonnay } \\
& +\mathrm{b}_{7} \text { sauv blanc }_{\mathrm{i}}+\mathrm{b}_{8} \text { white blend }_{\mathrm{i}}+\mathrm{b}_{9} \mathrm{JP}^{0.5}{ }_{\mathrm{i}} \\
& +\mathrm{b}_{10} \mathrm{JP}^{1}{ }_{\mathrm{i}}+\mathrm{b}_{11} \mathrm{JP}^{2}{ }_{\mathrm{i}}+\mathrm{b}_{12} \mathrm{JP}^{25}{ }_{\mathrm{i}}+\mathrm{b}_{13} \mathrm{JP}^{3}{ }_{\mathrm{i}} \\
& +\mathrm{b}_{14} \mathrm{JP}^{35}{ }_{\mathrm{i}}+\mathrm{b}_{15} \mathrm{JP}^{4}{ }_{\mathrm{i}}+\mathrm{b}_{16} \mathrm{JP}^{45}{ }_{\mathrm{i}}+\mathrm{b}_{17} \mathrm{~W}^{1}{ }_{\mathrm{i}} \\
& +\mathrm{b}_{18} \mathrm{~W}^{2}{ }_{\mathrm{i}}+\mathrm{b}_{19} \mathrm{~W}^{25}{ }_{\mathrm{i}}+\mathrm{b}_{20} \mathrm{~W}^{3}{ }_{\mathrm{i}}+\mathrm{b}_{21} \mathrm{~W}^{35}{ }_{\mathrm{i}} \\
& +\mathrm{b}_{22} \mathrm{~W}^{4}{ }_{\mathrm{i}}+\mathrm{b}_{23} \mathrm{~W}^{45}{ }_{\mathrm{i}}+\mathrm{b}_{24} \mathrm{~W}^{5}{ }_{\mathrm{i}}
\end{aligned}
$$

where $\mathrm{OV}_{\mathrm{i}}=$ ordinal valuation of wine $\mathrm{i}, \mathrm{DV}_{\mathrm{i}}=$ dummy valuation of wine $i$, Wine Stars $=$ Wine rating of wine i, Platter Stars $=$ Platter's Wine Guide rating of wine i, cabernet $=1$ if wine $\mathrm{i}$ is a Cabernet Sauvignon, 0 if otherwise, merlot $=1$ if wine $i$ is a Merlot, 0 if otherwise, pinot noir $=1$ if wine $\mathrm{i}$ is a Pinot Noir, 0 if otherwise, shiraz $=1$ if wine $\mathrm{i}$ is a Shiraz, 0 if otherwise, red blend $=1$ if wine $i$ is a red blend, 0 if otherwise, chardonnay $=1$ if wine $\mathrm{i}$ is a Chardonnay, 0 if otherwise, sauv blanc $=1$ if wine $i$ is a Sauvignon Blanc, 0 if otherwise, white blend $=1$ if wine $\mathrm{i}$ is a white blend, 0 if otherwise, $\mathrm{JP}^{0.5}=1$ if wine i obtained 0.5 Platter's Wine Guide stars, 0 if otherwise, $\mathrm{JP}^{1}=1$ if wine $\mathrm{i}$ obtained 1 Platter's Wine Guide stars, 0 if otherwise, $\mathrm{JP}^{2}=1$ if wine i obtained 2 Platter's Wine Guide stars, 0 if otherwise, $\mathrm{JP}^{25}=1$ if wine i obtained 2.5 Platter's Wine Guide stars, 0 if otherwise, $\mathrm{JP}^{3}=1$ if wine i obtained 3 Platter's Wine Guide stars, 0 if otherwise, $\mathrm{JP}^{35}=1$ if wine i obtained 3.5 Platter's Wine Guide stars, 0 if otherwise, $\mathrm{JP}^{4}=1$ if wine i obtained 4 Platter's Wine Guide stars, 0 if otherwise, $\mathrm{JP}^{45}=1$ if wine i obtained 4.5 Platter's Wine Guide stars, 0 if otherwise, $\mathrm{W}^{1}=1$ if wine $\mathrm{i}$ obtained 1 Wine stars, 0 if otherwise, $\mathrm{W}^{2}=1$ if wine $\mathrm{i}$ obtained 2 Wine stars, 0 if otherwise, $\mathrm{W}^{25}=1$ if wine $\mathrm{i}$ obtained 2.5 Wine stars, 0 if otherwise, $\mathrm{W}^{3}=1$ if wine $\mathrm{i}$ obtained 3 Wine stars, 0 if otherwise, $\mathrm{W}^{35}=1$ if wine $\mathrm{i}$ obtained 3.5 Wine stars, 0 if otherwise, $\mathrm{W}^{4}=1$ if wine $\mathrm{i}$ obtained 4 Wine stars, 0 if otherwise, $\mathrm{W}^{45}=1$ if wine $\mathrm{i}$ obtained 4.5 Wine stars, 0 if otherwise, $\mathrm{W}^{5}=1$ if wine $\mathrm{i}$ obtained 5 Wine stars, 0 if otherwise.

\section{Empirical analysis}

\section{Preliminary analysis}

Figures 1 and 2 illustrate the average price (in rand) awarded to white wines during the 2007 period. Note that for sake of space and by way of contrast to the 2006 paper by Priilaid and van Rensburg ${ }^{19}$ that featured only red cultivars, only scattergrams relating to white wines are featured in this article. Sighted and blind ratings are illustrated in Figures 1 and 2 , respectively.

Close scrutiny of these scattergrams (particularly those derived from the sighted scores), reveals the nonlinearity of 


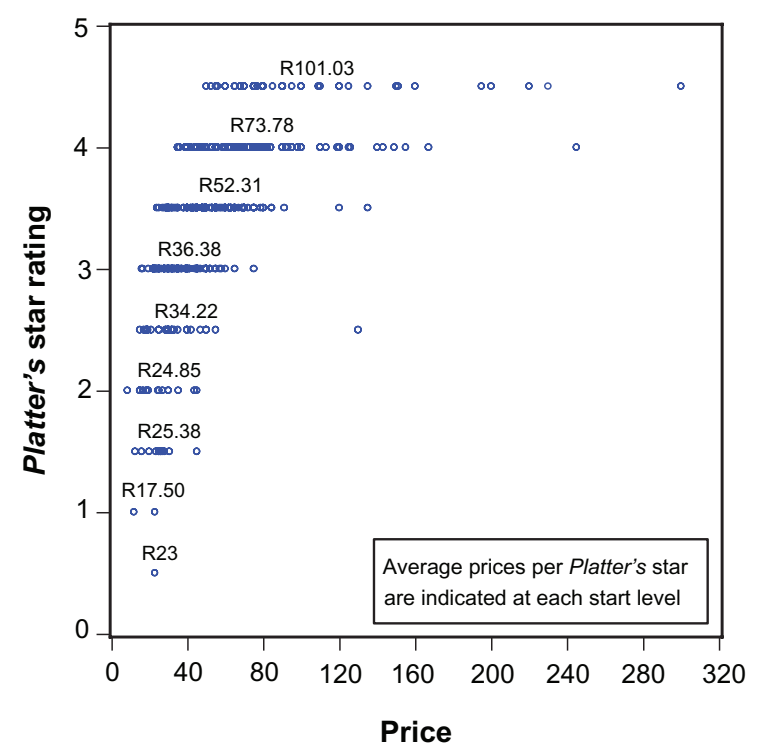

Figure I White wines 2007: wine prices (in rand) per John Platter's South African Wine Guide $^{42}$ star conferred.

the price-star relationship, this particularly from three stars upwards. At the zero- and one-star level, mispricing is also prevalent. The extent of mispricing at the lower levels of quality is not as apparent in the sample of sighted assessments. In all cases, the degree to which specific cultivars impact on price per star is uncertain.

To control for multicollinearity, correlations were computed for all model variables as they appear in their form as ratio-styled data (see Table 4). For both the red and white sample, the blind-sighted correlations are relatively low ( 0.30 for red and 0.40 for white), suggesting that both

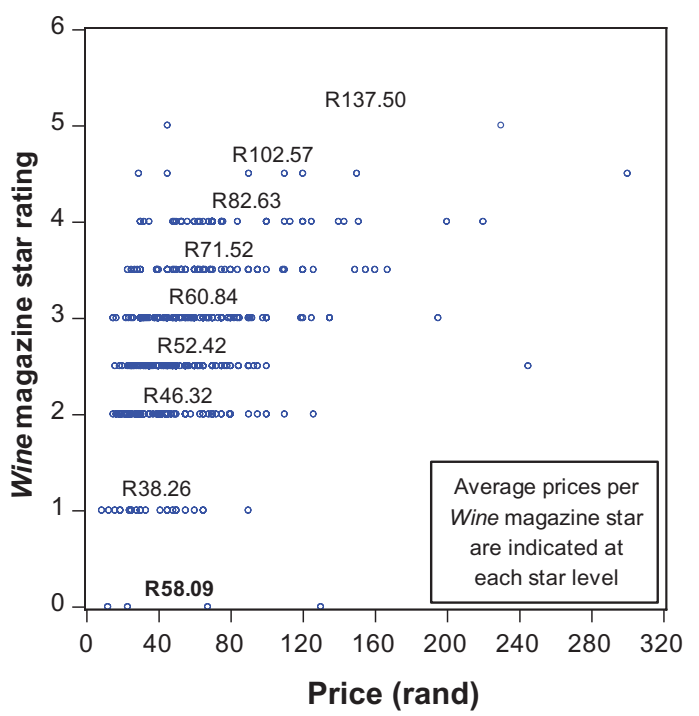

Figure 2 White wines 2007: prices (in rand) per Wine ${ }^{39}$ star conferred. styles of assessment supply explanatory power without fear of extreme multicollinearity. Not surprisingly, the price variable is most highly correlated with Platter's sighted scores (red correlation $=0.50$, white correlation $=0.60$ ) and then only with Wine's blind scores (red correlation $=0.25$, white $=0.39$ ).

Proceeding from these descriptive statistics, ordinal and "dummy-styled" OLS models are computed for each of the blind and sighted assessment metrics, and subsequently compared. For the varietal and sighted and blind ratings, the dummy comparators in this analysis are Pinotage and Chenin Blanc (in the case of the red and white subsets) and one-and-a-half Platter's stars and zero Wine stars. All regressions were tested for heteroskedasticity, though none was apparent.

\section{Price versus value}

For comparative purposes, final linear and dummy-styled regressions are computed to model wine value, and appear in Tables 5 (for red) and 6 (for white).

The consequent (final linear and dummy) price-value scattergrams are then presented in Figures 3 and 4. With respect to the latter, by deploying the van Rensburg and Priilaid ${ }^{18}$ value and "rip-off" frontier typology, wines offering the most and least value for money, respectively, can thus be identified (see Figure 4).

With respect to the scattergrams (Figures 1 and 2), it becomes apparent that the dummy model provides a more realistic set of valuations. For red wines, the increase in the adjusted R-squared values from $26.73 \%$ (for the linear model) to $33.81 \%$ (for the dummy model) implies a price correlation improvement of over $26 \%$. With white wine adjusted R-squared values increasing from $41.96 \%$ (for the linear model) to $50.48 \%$ (for the dummy), the price correlation improves by over $20 \%$. Across all but the upper price segment within the red wine dataset, the linear and dummy

Table 4 Red and white wines 2007: correlation matrix of prices and star ratings

\begin{tabular}{lll}
\hline Price & Wine $^{39}$ & $\begin{array}{l}\text { John Platter's South African } \\
\text { Wine Guide }^{42}\end{array}$ \\
\hline Reds 2007 & \\
1.00 & & \\
0.25 & 1.00 & \\
0.50 & 0.30 & 1.00 \\
Whites 2007 & & \\
1.00 & & \\
0.39 & 1.00 & \\
0.60 & 0.40 & 1.00 \\
\hline
\end{tabular}


Table 5 All red wines 2007: the final linear and dummy model regressions for all wine ratings

\begin{tabular}{|c|c|c|}
\hline Variable & Coefficient & t-statistic \\
\hline \multicolumn{3}{|c|}{ Linear model for blind (Wine ${ }^{39}$ ) and sighted (John Platter's South African } \\
\hline \multicolumn{3}{|c|}{ Wine Guide ${ }^{42}$ ) assessments $\left(R^{2}: 26.73 \%, n=896\right)$} \\
\hline Constant & -117.59 & -8.69 \\
\hline Shiraz & 12.62 & 2.41 \\
\hline Cabernet Sauvignon & 0.93 & 0.19 \\
\hline Merlot & 5.17 & 1.12 \\
\hline Pinot Noir & 32.70 & 2.72 \\
\hline Red blends & 15.75 & 3.28 \\
\hline Platter's Wine Guide & 48.78 & 13.34 \\
\hline Wine & 7.43 & 3.59 \\
\hline \multicolumn{3}{|c|}{ Dummy model for blind (Wine) and sighted (John Platter's South African } \\
\hline \multicolumn{3}{|c|}{ Wine Guide) (Adj. R²: 33.81\%, $n=896)$} \\
\hline Constant & 33.05 & 3.22 \\
\hline Shiraz & 14.27 & 2.98 \\
\hline Cabernet Sauvignon & 2.23 & 0.52 \\
\hline Merlot & 6.42 & 1.48 \\
\hline Pinot Noir & 28.64 & 2.54 \\
\hline Red blends & 15.32 & 3.38 \\
\hline Platter's Wine Guide 2 stars & -6.24 & -0.64 \\
\hline Platter's Wine Guide 2.5 stars & -1.38 & -0.15 \\
\hline Platter's Wine Guide 3 stars & 10.08 & 1.11 \\
\hline Platter's Wine Guide 3.5 stars & 24.13 & 2.78 \\
\hline Platter's Wine Guide 4 stars & 44.68 & 5.00 \\
\hline Platter's Wine Guide 4.5 stars & 115.60 & 9.50 \\
\hline Wine Istar & -0.59 & -0.07 \\
\hline Wine 2 stars & -1.54 & -0.23 \\
\hline Wine 2.5 stars & 0.78 & 0.12 \\
\hline Wine 3 stars & 7.36 & 1.10 \\
\hline Wine 3.5 stars & 17.57 & 1.94 \\
\hline Wine 4 stars & 17.28 & 1.99 \\
\hline Wine 4.5 stars & 1.27 & 0.04 \\
\hline Wine 5 stars & 91.53 & $7.8 I$ \\
\hline
\end{tabular}

Note: Significant $t$-statistic figures and their respective coefficients are cited in bold.

valuation averages appear roughly equivalent (see Table 7). However, in the more expensive R150-R199.99 and R200plus price segments, where each additional increment in wine quality requires further serious outlays of capital, dummy valuations appear considerably more affected. For example, within the R150-R199.99 segment, the average dummy valuation is $\mathrm{R} 139.01,13 \%$ greater than the average linear valuation of R122.51. Within the premium R200-plus price segment, the average dummy valuation increases to $\mathrm{R} 152.16,17 \%$ greater than the average linear valuation of R130.07. Even more significant, however, is the dispersal of values across the upper and lower price segments. Within the lower price segment, the dummy approach enforces a standard deviation decrease of $43 \%$. In the upper price segment, the spread increases by more than twice that amount: $99 \%$.
Table 6 White wines 2007: the final linear and dummy model regressions for all wine ratings

\begin{tabular}{|c|c|c|}
\hline Variable & Coefficient & t-statistic \\
\hline \multicolumn{3}{|c|}{ Linear model for blind (Wine ${ }^{39}$ ) and sighted (John Platter's South African } \\
\hline \multicolumn{3}{|c|}{ Wine Guide $\left.{ }^{42}\right)\left(R^{2}: 4 I .96 \%, n=462\right)$} \\
\hline Constant & $-51.4 I$ & -5.97 \\
\hline Chardonnay & 16.59 & 4.72 \\
\hline Sauvignon Blanc & 4.74 & 1.59 \\
\hline White blends & 10.70 & 2.44 \\
\hline Wine stars & 23.47 & 12.83 \\
\hline Platter's Wine Guide & 7.39 & 3.56 \\
\hline \multicolumn{3}{|c|}{ Dummy model for blind (Wine) and sighted (John Platter's South African } \\
\hline \multicolumn{3}{|c|}{ Wine Guide) ( $\left.\mathrm{R}^{2}: 50.48 \%, \mathrm{n}=462\right)$} \\
\hline Constant & 52.90 & 2.14 \\
\hline Chardonnay & 19.81 & 6.56 \\
\hline Sauvignon Blanc & 6.93 & 2.66 \\
\hline White blends & 12.64 & 3.46 \\
\hline Wine I star & -38.61 & -1.56 \\
\hline Wine 2 stars & -36.11 & -1.46 \\
\hline Wine 2.5 stars & -34.27 & -1.39 \\
\hline Wine 3 stars & -29.94 & -1.21 \\
\hline Wine 3.5 stars & -29.74 & -1.19 \\
\hline Wine 4 stars & -19.57 & -0.78 \\
\hline Wine 4.5 stars & 15.08 & 0.42 \\
\hline Wine 5 stars & 50.20 & 0.95 \\
\hline Platter's Wine Guide 0.5 star & -29.90 & -1.21 \\
\hline Platter's Wine Guide Istar & -21.73 & -1.16 \\
\hline Platter's Wine Guide 2 stars & -0.73 & -0.18 \\
\hline Platter's Wine Guide 2.5 stars & 6.95 & 2.03 \\
\hline Platter's Wine Guide 3 stars & 6.83 & 2.33 \\
\hline Platter's Wine Guide 3.5 stars & 21.30 & 6.96 \\
\hline Platter's Wine Guide 4 stars & 38.70 & 10.84 \\
\hline Platter's Wine Guide 4.5 stars & 61.98 & 11.00 \\
\hline
\end{tabular}

Note: Significant $t$-statistic figures and their respective coefficients are cited in bold.

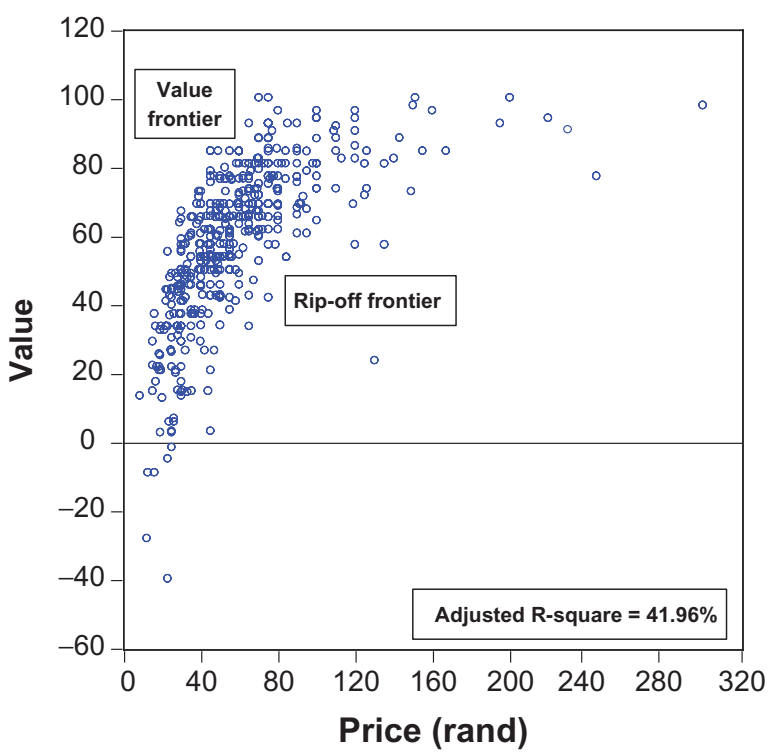

Figure 3 White wines 2007; price versus value (in rand): the final linear model. 


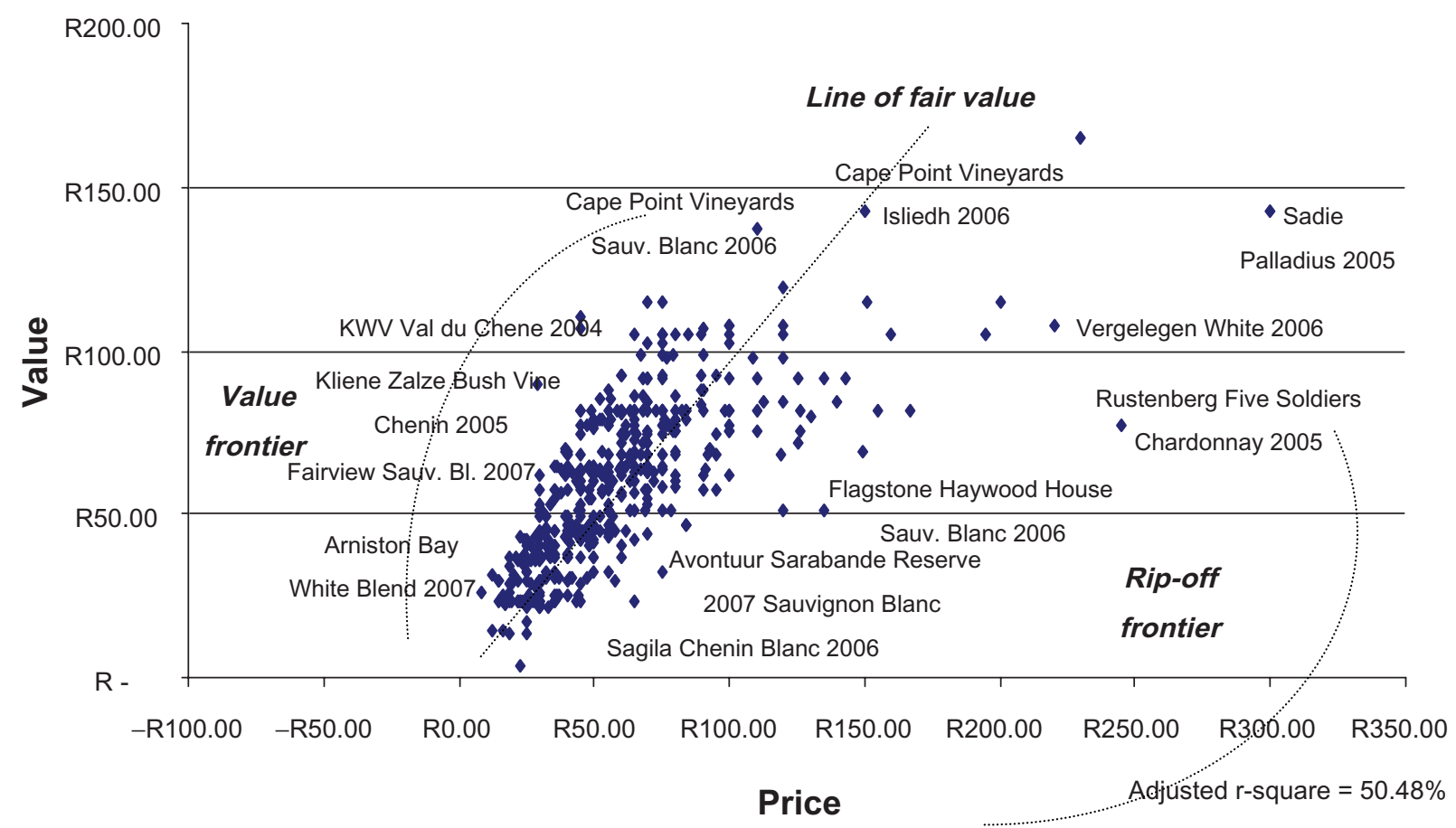

Figure 4 White wines 2007; price versus value (in rand): the final dummy-styled model.

Notes: Using a nonlinear specification, statistically significant variables include all varietals as well as John Platter's South African Wine Guide ${ }^{42}$ stars 2.5 to 4.5 . Once more wines offering the most value for money can be found on the "value frontier," and include Arniston Bay (a white blend), Fairview's Sauvignon Blanc, Kleine Zalze's bush vine Chenin, the KWV Val Du Chêne, and the Cape Point Vineyards Sauvignon Blanc. Similarly, wines offering the least value for money accrue on or about the so-called "rip-off' frontier. Such wines include the Sagila Chenin Blanc, the Avontuur Sarabande reserve Sauvignon Blanc, the Haywood House Sauvignon Blanc from Flagstone, the Rustenberg Five Soldiers Chardonnay and the Vergelegen White. The "line of fair value" falls between these two extremes and showcases wines (such as the Isliedh from Cape Point Vineyards) that are fairly priced for the quality and hence value on offer. In contrast to the linear multifactor model, we note the absence of any negative valuations and 30 wines valued at over RI00. In the linear construction, only four wines are valued at over RI00.

Table 7 Red and white wines 2007: final linear and dummy model regressions for all wine ratings

\begin{tabular}{|c|c|c|c|c|}
\hline Price segment & & $\begin{array}{l}\text { Linear } \\
\text { model }\end{array}$ & $\begin{array}{l}\text { Dummy } \\
\text { model }\end{array}$ & $\begin{array}{l}\text { Percentage } \\
\text { change }\end{array}$ \\
\hline \multicolumn{5}{|l|}{ Red wines } \\
\hline \multirow[t]{2}{*}{ Less than R50.00 ( $n=202$, avg price: $R 38.57)$} & Average valuation & R58.44 & $\mathrm{R} 60.70$ & $4 \%$ \\
\hline & Value SD & R3I.33 & RI7.17 & $-43 \%$ \\
\hline \multirow[t]{2}{*}{ R50-R99.99 ( $n=449$, avg price: $R 71.69)$} & Average valuation & R88.44 & R84.05 & $-5 \%$ \\
\hline & Value SD & R27.77 & $\mathrm{R} 29.75$ & $7 \%$ \\
\hline \multirow[t]{2}{*}{ RI00-RI49.99 ( $n=\mid 44$, avg price: $R|| 8.05)$} & Average valuation & RI08.II & 105.26 & $-3 \%$ \\
\hline & Value SD & R22.06 & R35.57 & $61 \%$ \\
\hline \multirow[t]{2}{*}{$\mathrm{R}|50-\mathrm{R}| 99.99(\mathrm{n}=54$, avg price: $\mathrm{R} \mid 64.26)$} & Average valuation & $\mathrm{R} \mid 22.5 \mathrm{I}$ & RI39.0I & $13 \%$ \\
\hline & Value SD & R20.04 & R39.77 & $97 \%$ \\
\hline \multirow[t]{2}{*}{ More than R200 ( $n=47$, avg price: R297.13) } & Average valuation & $\mathrm{R} / 30.07$ & RI52.16 & $17 \%$ \\
\hline & Value SD & R20.54 & $\mathrm{R} 40.83$ & $99 \%$ \\
\hline \multicolumn{5}{|l|}{ White wines } \\
\hline \multirow[t]{2}{*}{ Less than $\mathrm{R} 50.00$ ( $n=210$, avg price: $\mathrm{R} 33.92)$} & Average valuation & R43.2I & R4I.3I & $-4 \%$ \\
\hline & Value SD & R20.32 & $R 16.67$ & $-18 \%$ \\
\hline \multirow{2}{*}{ R50-R99.99 ( $n=208$, avg price: R67.37) } & Average valuation & $R 69.37$ & R69.13 & $0 \%$ \\
\hline & Value SD & $R \mid 2.96$ & RI7.97 & $39 \%$ \\
\hline \multirow{2}{*}{$R|00-R| 49.99(n=33$, avg price: $R|| 6.2 \mid)$} & Average valuation & R79.47 & R86.38 & $9 \%$ \\
\hline & Value SD & $\mathrm{R} \mid 4.20$ & $\mathrm{R} 18.17$ & $28 \%$ \\
\hline \multirow[t]{2}{*}{ RI50-RI99.99 ( $n=6$, avg price: $R \mid 63.00)$} & Average valuation & $\mathrm{R} 92.98$ & RI05.I2 & $13 \%$ \\
\hline & Value SD & R6.70 & $\mathrm{R} 22.82$ & $241 \%$ \\
\hline \multirow[t]{2}{*}{ More than R200 ( $n=5$, avg price: R239.00) } & Average valuation & $\mathrm{R} 92.32$ & $\mathrm{R}|2| .57$ & $32 \%$ \\
\hline & Value SD & R8.99 & R33.68 & $275 \%$ \\
\hline
\end{tabular}

Abbreviations: avg, average; SD, standard deviation. 
Moving through each of the four price segments within the white wine dataset, we see a similar pattern. Once more, the linear and dummy valuation averages appear roughly the same for low- to medium-priced wines (see Table 7). However, within the R100-R149.99 segment, the average dummy valuation is $\mathrm{R} 86.38$, $9 \%$ greater than the average linear valuation of R79.47. Between R150 and R199.99, the variation between dummy valuations (average $=\mathrm{R} 105.12$ ) and their linear versions (average $=$ R92.98) jumps to over $13 \%$. These increases pale in comparison to the variation evinced in the premium-plus R200-plus price segment. Here, the average dummy valuation is $\mathrm{R} 121.57,32 \%$ greater than the average linear valuation of R92.32.

A study of the measure of spread across the various white wine price segments is also revealing. Within the lower price segment, the dummy approach enforces a standard deviation decrease of between $4 \%$ and $18 \%$. As with the red wine dataset however, in the upper price segments the linear to dummy spread increases dramatically: $241 \%$ in the R150 to R199 category, and 275\% in the R200-plus.

\section{Value versus mispricing}

This final subsection considers the degree to which the relationship between value and extent of mispricing alters between the linear and dummy approaches. (For white wines see Figures 5 and 6.)

For both red and white wine datasets, an examination of the value to extent of mispricing relationship reveals four noteworthy features, all of which echo and confirm the earlier findings by Priilaid and van Rensburg ${ }^{19}$ conducted on an independent dataset.

1. The spread of mispricing reduces significantly from the linear to the dummy version. In the case of red wines, the linear spread is $438.5 \%$ (166.2\% to $-272.3 \%)$ compared with $312.7 \%$ ( $86.0 \%$ to $-226.7 \%)$ in the dummy version. Similar to the white wines, the linear spread is $474.2 \%$ (332.9\% to $-141.3 \%$ ) compared with $291.5 \%(83.3 \%$ to $-208.2 \%)$ in the dummy version. A survey of the standard error of regression for each of the four final models yields a similar result. In the final red valuation models, the standard error drops from 55.70 (linear model) to 52.94 (dummy model). The final white wine valuations reveal a similar pattern of standard errors: linear model, 26.26; dummy model, 24.22.

2. Both at the bottom and top end of the quality continuum, valuations predicted by the dummy model are markedly higher than those predicted by the linear model. At the

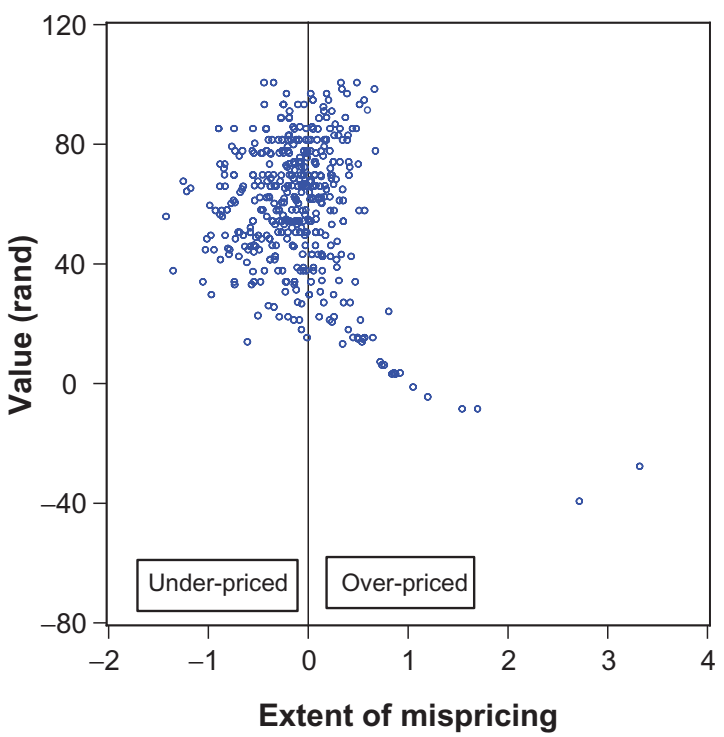

Figure 5 White wines 2007; extent of mispricing versus value (in rand): the final linear model.

bottom end, for example, whereas in the instance of red wines the lowest 15 linear valuations are all negative, with a lowest valuation of $-\mathrm{R} 36.05$ and an average of $-\mathrm{R} 13.87$, in the dummy style valuations, the corresponding figures are R27.50 for the lowest valuation and a far more realistic R31.04 for the bottom 15 average. The same can also be said of white wines. Of the lowest 15 linear valuations, six are negative, with the lowest at $-\mathrm{R} 39.68$. The average of these 15 is R2.23. By comparison, the average for the lowest 15 dummy valuations is a more realistic R18.29, and no negative valuations are derived. At the top end we see the same: the highest linear valuation is R100.34,

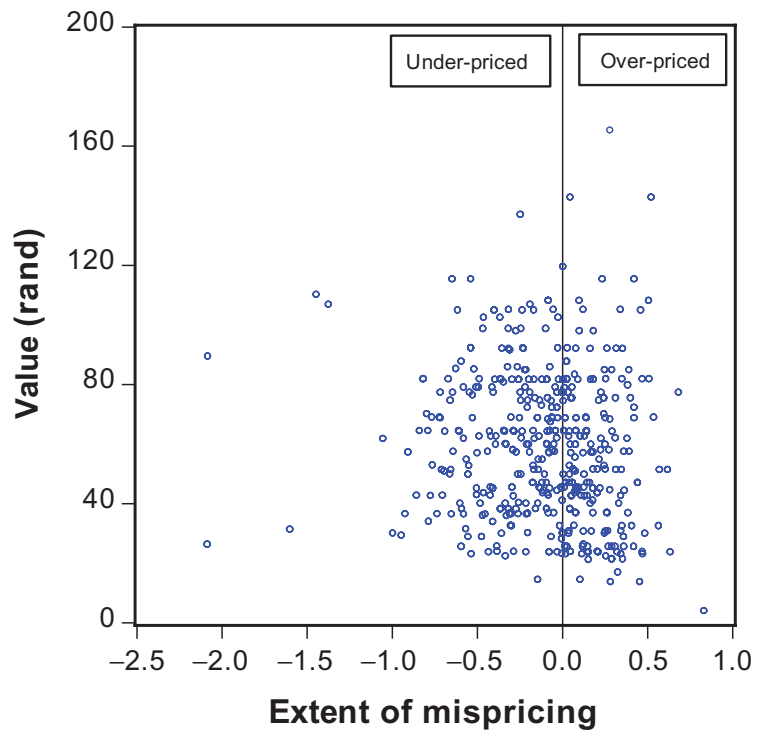

Figure 6 White wines 2007; extent of mispricing versus value (in rand): the final dummy-styled model. 


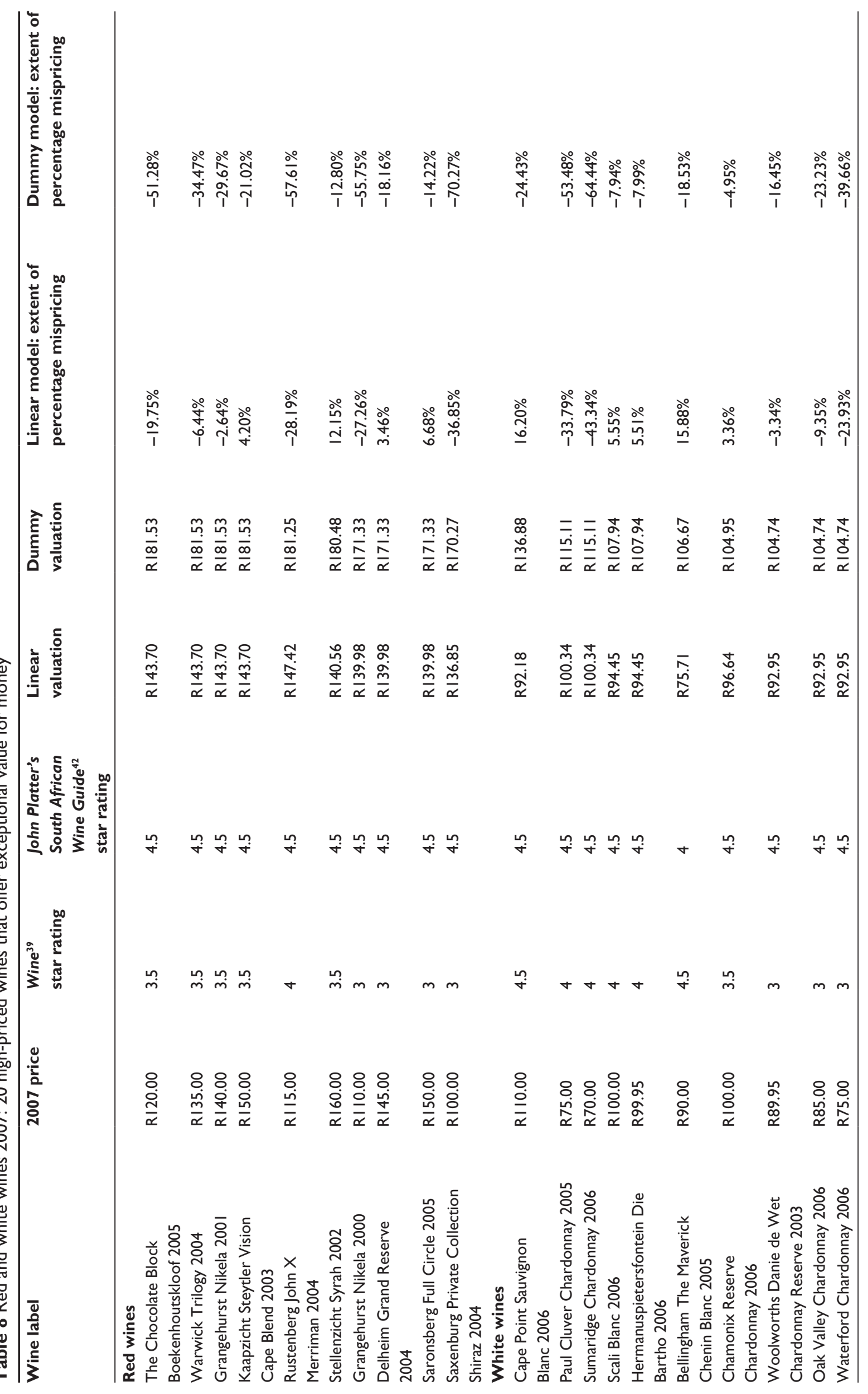


markedly lower than its dummy equivalent: R165.09. Across the top 15 linear and dummy valuations, the trend is similar: the linear top 15 average is R97.00 versus the dummy average of R121.02.

3. In the case of both red and white wine datasets, while the relationship between value and the extent of mispricing is random in the linear version (see Figure 5 for white wines), the extent of scatter becomes that much more apparent in the dummy approach (see Figure 6 for white wines).

4. In terms of the above, we note that through the application of properly conceived valuation techniques, fertile areas for bargain hunting can thus be found at the top of the price continuum as much as at the bottom. Table 8's well-stocked list of premium value-for-money red and white wines serves to corroborate this point; with linear models this would simply not happen.

\section{Conclusion}

In the preface to a new South African bargain listing booklet, ${ }^{39}$ which used the self-same dummy-styled pricing model presented in this analysis, Wine editor Cathryn Henderson observed that while controversial, blind and sighted ratings serve as a means to interpret an overload of information and, thus, within the clutter of the wine marketplace they help consumers narrow down the options on hand. So saying, Henderson also remarked how often sighted and blind methods of tasting wine produce different scores. While cues like region, price, and label can detract from the intrinsic merit of the wine itself, exterior influences like heritage and particular wine making philosophies certainly have their own place in the world of wine, she opined. Using both sighted and blind based scores, the "WineIQ calculation acknowledges the merits of each, and takes both methods and the resultant rating into account, as well as the all important factor in any purchase: value-for-money," she concluded.

Henderson's commentary is insightful in that for the first time in South Africa, the melding of the two sometimesincompatible styles of blind and sighted tasting could now enable consumers to make informed purchase decisions based on the simultaneous appraisal of both price and the two versions of wine quality. The booklet cited over 600 bargain wines, ranging in price from R17.10 to R230.

Notwithstanding the launch of this publication, there remains a degree of skepticism in the industry toward such guides - typically because, it is claimed, they do not help the industry to sell wines using the stock techniques of branding and self-promotion. As invitations to purchase, these techniques typically invoke an array of cue assemblages including aging quality, vineyard prestige, wine complexity, diversity of range, esoteric wine language, award stickers, and labeling in general. In terms of the latter, drinkers of South African wine are subjected to a diversity of fonts ranging from crude to sophisticated, the occasional African wild animal, gestures of Dutch gabling, and frequently some suitably unpronounceable estate names. In their 2005 analysis of the US wine market, Kim and Mauborgne ${ }^{43}$ observed that to the novice consumer it is the uniformity of these cues, and not their differential deployment, that has the most impact. Consequently, the market appears to the consumer both uniformly confusing and without obvious differentiation.

Breaking from these blunted marketing techniques, this paper's stripped-down dummy-style approach to wine price modeling is explicitly customer facing and forsakes all other cue additions, construing these as baffling noise and mere distraction. Its constitution cleaves to Thrane's ${ }^{17}$ view that customers would be better served with a simplified set of relevant hedonic cues than by a plethora of irrelevant product-driven alternatives that serve merely to justify the price being asked. While such cues may increase price-value correlations and hence prove more statistically relevant, this practice occurs at the expense of serving the consumer's best interests.

With wine rating information increasingly available to consumers, there are certain consequences that stem from the argument above for the industry at large. First, customerfacing hedonic pricing enables consumers to both identify fair-priced quality wines and to avoid paying for overpriced "hyped-up" wines. Secondly, working from the fitted values of the nonordinal models developed here, producers can accurately price their wines either as loss leaders, fully priced premium wines, or fairly priced offerings. Such insight consequently provides producers with the means to move their product through appropriate pricing (or repricing) strategies. Thirdly, for the retailer, the ability to identify wines on or about the "value frontier" enables them to pre-emptively purchase stock that is likely to move faster than the norm, thus creating a "value offering" that will attract customers and hence gain market share.

Clearly, the formulation of simplified and properly specified pricing models is critical and it was this, along with an exploration of the connections between a wine's price, its value, and, hence, value for money, that formed the focus of this study. Here, two pricing models were created from a dataset of some 1358 South African red and white wines obtainable during the year 2007. With 
the underpinning hypothesis that consecutive quality increments are not similarly priced, the analysis presented sought to value wines that, in conjunction with intrinsic grape variety, employed a combination of blind and sighted wine assessments drawn from available accounts of professional wine critics.

Such is the current pressure within the wine industry that the ongoing availability of such data is of course no longer a given. In September 2011, Wine published its final hard copy edition and no further ratings have been forthcoming. The consequent availability of blind data going forward is thus by no means assured. Clearly, the lack of such data serves as a threat to the viability of price modeling and this certainly constitutes a weakness in this study. Without the necessary data - both blind and sighted - customer-facing accounts of wine value will not be possible. Additionally, it should be noted that no objective, climatic, or chemical attributes were included for other than those implicit in the blind and sighted ratings themselves. To some this may represent a level of weakness in the hedonic computation of values derived. Once more, in our defense, the rationale throughout this study was one of producing a demand side account of wine values that computes and identifies wines that offer significant value for money to the customer. Specific to this is a view that wine consumers will, and will increasingly, employ wine media ratings to search out wines that offer value for money.

Underpinned by this perspective, the consequent analysis of our statistical output confirms that dummy-styled modeling techniques do much to address the problems associated with linear pricing models. Therefore, and with a more recent and expanded dataset, this analysis affirms Priilaid and van Rensburg's earlier work ${ }^{19}$ on the bias-reducing effect of substituting conventional linear calibrations with binary or dummy variables.

\section{Disclosure}

This paper follows on from a prior version entitled "The use of hedonic pricing in the valuation of South African wines" presented by the authors at the 22nd Conference of the South African Institute of Management Scientists (SAIMS), September 12-15, 2010, Mpekweni Beach Resort, hosted by Rhodes University, and published in the SAIMS Conference Proceedings. Other than in the ongoing development of customer-facing wine bargainspotting models, there is no conflict of interest pertaining to the content of this paper and any work done by either of its authors.

\section{References}

1. Oczkowski E.A hedonic price function for Australian premium table wine. Australian Journal of Agricultural Economics. 1994;(38):93-110.

2. Oczkowski E. Hedonic price functions and measurement error. Economic Record. 2001;(77):374-382.

3. Nerlove M. Hedonic price functions and the measurement of preferences: The case of Swedish wine consumers. European Economic Review. 1995;39(9):1697-1716.

4. Coombris P, Lecocq S, Visser M. Estimation for a hedonic price equation for Bordeaux wine: Does quality matter? The Economic Journal. 1997;107(441):390-402.

5. Landon $\mathrm{S}$, Smith $\mathrm{CE}$. The use of quality and reputation indicators by consumers: The case of Bordeaux wine. Journal of Consumer Policy. 1997;12(1):79-82.

6. Landon S, Smith CE. Quality expectations, reputation and price. The Southern Economic Journal. 1998;64(3):628-647.

7. Blair D, Burley H. A preliminary pricing analysis of Australian red wine. Wine Industry Journal. 1998;13(4):414-416.

8. Wade C. Reputation and its effect on the price of Australian wine. Wine Industry Journal. 1999;14(14):82-84.

9. Angulo AM, Gil JM, Gracia A, Sánchez M. Hedonic prices for Spanish red wine quality. British Food Journal. 2000;102(7):481-493.

10. Corsi A, Ashenfelter O. Predicting Italian wines quality from weather data and experts ratings. Proceedings of the 7th Oenometrics Conference; May 11-13, 2000; Riems, France.

11. Schamel G. Individual and collective reputation indicators of wine quality. CIES Discussion Paper 0009. Centre for International Economic Studies, University of Adelaide, Australia, 2000.

12. Schamel G. Anderson K. Wine quality and varietal, regional, and winery reputations: hedonic prices for Australia and New Zealand. CIES Workshop Paper 20. Centre for International Economic Studies, University of Adelaide, Australia, 2001.

13. Ling B, Lockshin L. Components of wine prices for Australian wine: How winery reputation, wine quality, region, vintage, and winery size contribute to price of varietal wines. Australasian Marketing Journal. 2003;11(3):19-31.

14. Bombrun H, Sumner DA. What determines the price of wine? AIC Issues Brief. 2003;18:1-6.

15. Wood D, Anderson K. What determines the future value of an icon wine? New evidence from Australia. Proceedings of the 4th Oenometrics Conference; May 22-23, 2003; Budapest, Hungary.

16. Cardebat J, Figuet J. What explains Bordeaux prices? Applied Economic Letters. 2004;11:293-296.

17. Thrane C. In defence of the price hedonic model in wine research. Journal of Wine Research. 2004;15:123-134.

18. van Rensburg P, Priilaid D. An econometric model for identifying value in South African red wine. International Journal of Wine Marketing. 2004;16(1):37-53.

19. Priilaid D, van Rensburg P. Non-linearity in the hedonic pricing of South African red wines. International Journal of Wine Marketing. 2006;18(3):166-182.

20. Triplett JE. The economic interpretation of hedonic methods. Survey of Current Business. 2004;66:36-40.

21. Bartik TJ. The estimation of demand parameters in hedonic price models. Journal of Political Economy. 1987;95(11):81-88.

22. Goodman AC. Andrew Court and the invention of hedonic price analysis. Journal of Urban Economics. 1998;44:291-298.

23. Court AT. Hedonic price indexes with automotive examples. The Dynamics of Automobile Demand. New York: General Motors. 1939:98-119.

24. Waugh FV. Quality factors influencing vegetable prices. Journal of Farm Economics. 1928;10:185-196.

25. Malpezzi S. Hedonic Pricing Models: A Selective and Applied Review. Center for Urban Land Economics Research, University of Wisconsin, WI; 2002. Available from: http://www.bus.wisc.edu/realestate. Accessed April 23, 2008.

26. Freeman AM. The Measurement of Environmental Values. 2nd ed. Washington DC: Resources for the Future; 2004. 
27. Haas GC. Sales prices as a basis for farm land appraisal. Technical Bulletin 9. 1922; The University of Minnesota Agricultural Experiment Station: St Paul.

28. Metzemakers P, Louw E. Land as a production factor. Proceedings of the 45th Congress of the European Regional Science Association; August 23-27, 2005; Amsterdam, The Netherlands.

29. Ricardo D. On the Principles of Political Economy and Taxation. London: John Murray; 1817

30. Lecocq S, Visser M. What determines wine prices: Objective vs sensory characteristics. Journal of Wine Economics. 2006;1(1):42-56.

31. Ashenfelter O, Ashmore D, LaLonde R. Bordeaux wine vintage quality and the weather. Chance. 1995;8:7-14.

32. Priilaid D, van Rensburg P. Symbolic and functional brand effects in the hedonic assessment of South African wines. South African Journal of Business Management. 2010;41(4):47-69.

33. Peter JP, Olson JC. Consumer Behavior and Marketing Strategy. 6th ed. Boston, MA: McGraw-Hill Irwin; 2002.

34. Siegrist M, Cousin ME. Expectations influence sensory experience in a wine tasting. Appetite. 2009;52(3):762-765.

35. Priilaid D, Feinberg J, Carter O, Ross G. Follow the leader: how expert ratings mediate consumer assessments of hedonic quality. South African Journal of Business Management. 2009;40(4):15-22.
36. Morgan M. SA wine industry poised for 2010 fever. Breakwater Business. 2010;11(1):12-13.

37. Asimov E. Is there Still Hope for Syrah? The New York Times; 2010. Available from: http://www.nytimes.com/2010/06/02/dining/02pour. html. Accessed June 2, 2010.

38. Thomas S. Down to a Drop. Financial Mail; 2010. Available from: http:// www.fm.co.za/Article.aspx?id=112787. Accessed August 10, 2010.

39. Wine [magazine]. Henderson $\mathrm{C}$, editor. Cape Town: Ramsey Media; 2011. Available from: www.winemagazine.co.za. Accessed February 17, 2011.

40. Priilaid D. WineIQ - The Thinking Drinking Guide to Making a Smart Choice. Cape Town: Ramsay Media; 2011.

41. Boom C, editor. SA Wine Industry Directory 2006/7. 8th ed. Cape Town: Wineland Publications; 2006.

42. van Zyl P, editor. John Platter's South African Wine Guide. Cape Town: Andrew McDowell; 2012.

43. Kim W, Mauborgne R. Blue Ocean Strategy. Boston: Harvard Business School Press; 2005.
International Journal of Wine Research

\section{Publish your work in this journal}

The International Journal of Wine Research is an international, peer-reviewed open-access, online journal focusing on all scientific aspects of wine, including: vine growing; wine elaboration; human interaction with wine; and health aspects of wine. The journal provides an open access platform for the reporting

\section{Dovepress}

of evidence based studies on these topics. The manuscript management system is completely online and includes a very quick and fair peer-review system, which is all easy to use. Visit http://www.dovepress.com/testimonials.php to read real quotes from some of our published authors

Submit your manuscript here: http://www.dovepress.com/international-journal-of-wine-research-journalisease-journal 